\title{
Assessment of the internal stability of a dam core
}

\author{
Marc SMITH \\ P.E., Ph.D. ${ }^{1}$ \\ ${ }^{1}$ Dam Safety Division/Hydro Québec - 75 René-Lévesque west, Montréal, Québec, Canada H2Z1A4 \\ e-mail :smith.marc@hydro.qc.ca
}

\begin{abstract}
Internal erosion due to seepage forces represent one of the main causes of embankment dam safety incidents and failures. This phenomenon can initiate by internal instability where the finer particles in a dam core can erode through voids formed by the matrix of coarser particles. The assessment of internal stability of soils in existing dams or for future projects is of utmost importance for a dam owner. An application of three internal stability assessment methods based on the geometry of grain size distributions (construction control data) was realized for the silt-sand-gravel core of a $171 \mathrm{~m}$-high rockfill dam. This led to contradictory results. The representativeness of conclusions drawn from such applications should not be judged only by considering laboratory testing conditions used in establishing the various methods. Results from field monitoring data must also be taken into account. The use of grain size distribution criteria is a first step to assess internal stability. A thorough assessment of the internal stability of an existing dam would require the analysis of the core and filter materials by considering the spatial variability of their geotechnical properties as well as the interactions of geometric, hydraulic and mechanical susceptibilities to internal instability. Specific tests may be required for new projects particularly if the grain size distribution of soils under consideration is gap-graded or has a flat tail of fines.
\end{abstract}

Key words: Internal stability, suffusion, suffosion, till, field monitoring, embankment dam.

\section{Évaluation du risque d'instabilité interne dans un noyau de barrage en remblai}

L'érosion interne due aux forces d'écoulement représente une des causes principales d'incidents et de ruptures pour les barrages en remblai. Ce phénomène peut être initié par l'instabilité interne où les particules plus fines du noyau imperméable s'érodent à travers les vides formés par la matrice de particules plus grossières. L'évaluation du risque d'instabilité interne des ouvrages existants est particulièrement importante pour un propriétaire de barrages.

L'application de trois méthodes d'évaluation du risque d'instabilité interne basées sur la forme des courbes granulométriques (provenant des données de surveillance de la construction) a été réalisée pour le noyau de sable silteux graveleux d'un barrage en enrochement de $171 \mathrm{~m}$ de hauteur. Cet exercice donna des résultats contradictoires. La représentativité des conclusions tirées de l'application de ces méthodes ne doit pas être jugée en ne considérant que les conditions de laboratoire ayant servi à les établir. Les résultats provenant de l'auscultation du barrage doivent aussi être considérés. L'application de méthodes géométriques, basées sur les courbes granulométriques, est une première étape pour l'évaluation du risque d'instabilité interne. Une évaluation plus exhaustive doit inclure l'analyse des matériaux composant le noyau et aussi le filtre aval. La variabilité spatiale des propriétés géotechniques de ces sols doit être prise en compte tout comme les interrelations entre les caractéristiques géométriques, hydrauliques et mécaniques reliées au risque d'instabilité interne.

Des essais spécifiques peuvent être requis pour l'analyse d'ouvrages futurs surtout si la pente de la portion fine des courbes granulométriques prévues pour ces ouvrages est faible ou si ces courbes sont discontinues.

Mots-clefs : Instabilité interne, suffusion, suffosion, till, auscultation des ouvrages, barrage en remblai

\section{INTRODUCTION}

Internal erosion due to seepage forces represent one of the main causes of embankment dam safety incidents and failures. This phenomenon can initiate by internal instability where the finer particles in a soil can migrate through voids formed by the matrix of coarser particles. This could lead to a redistribution of fines in a soil which is often called "suffusion" in the literature. In other instances, it could lead to larger scale erosion and a loss of fines which is often referred to as "suffosion". These distinctions will not be made explicitly here, the term "internal stability" will be used in this paper. Considering the potential consequences of these erosion phenomena, the assessment of internal stability of soils in existing dams or for future projects is of utmost importance for a dam owner.
This paper will present a case study of the application of three methods to assess internal stability of an existing dam core using construction control data. These methods are based on the work of [Kenney, 1985-1986], of [Wan, 2008] and of [Lafleur, 1999]. They will be designated here as the KL method, the WF method and the Lafleur method respectively. The results from these applications will then be compared to field monitoring data to judge their representativeness.

\section{MAIN CHARACTERISTICS OF DAM}

The analyzed dam in this case study is part of a $880 \mathrm{MW}$ hydroelectric complex located in northern Québec, Canada. 
It is a $171 \mathrm{~m}$-high and $380 \mathrm{~m}$-long (station 1040 to 1420 ) rockfill structure with a central impervious core made of compacted non-plastic till. The dam, which has a total volume of $6.3 * 10^{6} \mathrm{~m}^{3}$, closes a narrow valley. The core and both upstream and downstream filter and transition zones are entirely founded on grouted rock. The dam was constructed from 1996 to 1998. The maximum reservoir level is $407 \mathrm{~m}$ and the crest elevation is $410 \mathrm{~m}$. The first impoundment started in 1998 and ended in 2002 when the reservoir level reached its maximum value.

\section{CONSTRUCTION CONTROL DATA}

The placement of till was realized by dumping and spreading the material in $0.45 \mathrm{~m}$-high lifts across the entire width of the core. Laboratory tests, which included the determination of grain size distributions by sieving (particles $>0.08 \mathrm{~mm}$ ) and hydrometer tests $(0.002 \mathrm{~mm}<$ particles $<0.08 \mathrm{~mm})$, were performed for construction control according to placed volume or as required. A total of 676 grain size distribution tests were realized in the core during construction. These tests included a total of 174 hydrometer tests. The results are presented on figure 1.

The till is a well-graded silty sand with gravel containing from $1 \%$ to $5 \%$ of particles $<0.002 \mathrm{~mm}$. Most of the grain size distributions do not show large variations from the mean values. The till placed in the core contains about $15 \%$ of particles from $40 \mathrm{~mm}$ to $300 \mathrm{~mm}$. The grain size distributions were regraded on the fraction passing $40 \mathrm{~mm}$ (see figure 1) to correspond to the mean maximum diameter of soils tested to establish the KL, WF and Lafleur methods and therefore to facilitate comparisons.

This case study considers the hydrometer tests located at the maximum section (station 1235) $\pm 50 \mathrm{~m}$. This interval corresponds approximately to the horizontal distance covered during till placement between two tests. Figure 2 shows a cross section of the central part of the dam at station 1235 and a projection of the location of hydrometer tests realized at $\pm 50 \mathrm{~m}$.

The grain size distributions located on figure 2 are used to assess the internal stability of the dam core.

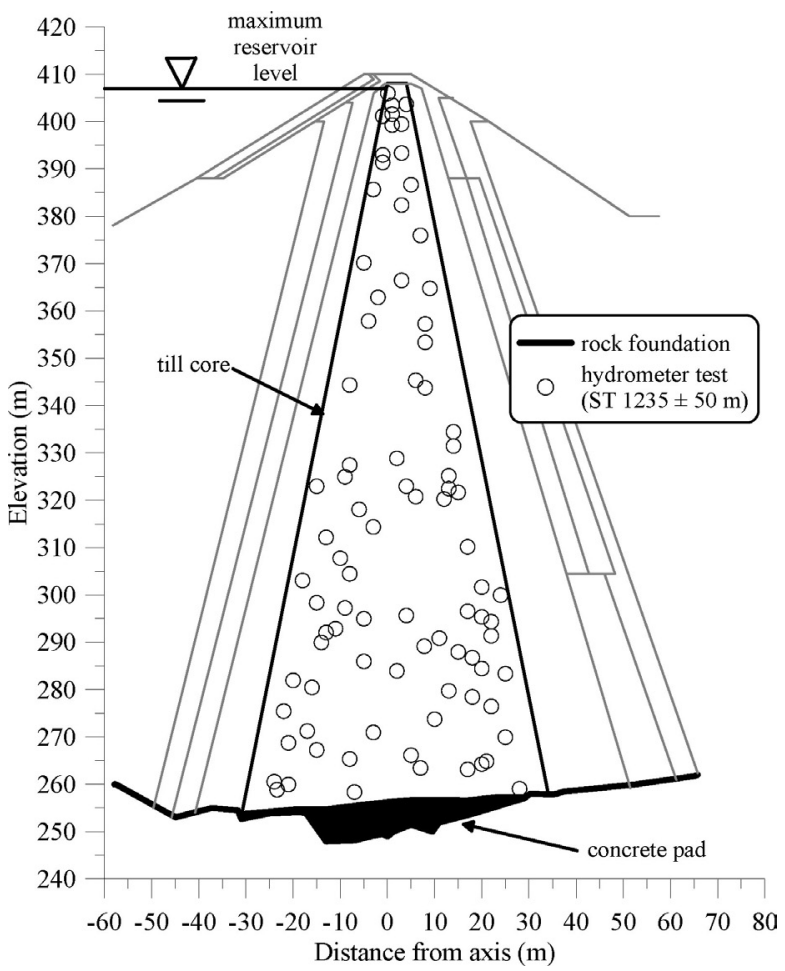

Figure 2 : Spatial location of hydrometer tests at station $1235 \pm 50 \mathrm{~m}$

\section{APPLICATION OF INTERNAL STABILITY ASSESSMENT METHODS}

\section{IV.1. KL method}

The KL method was developed by testing sandy soils to be used as dam filters. It considers the shape of the grain size curve in the finer portion. It is commonly used in Canada to assess internal stability of the impervious core of existing dams although the method was not specifically developed for well-graded silty soils. Also, some of the testing conditions, namely the use of vibrations and higher seepage velocities, are more severe than the conditions typically encountered in

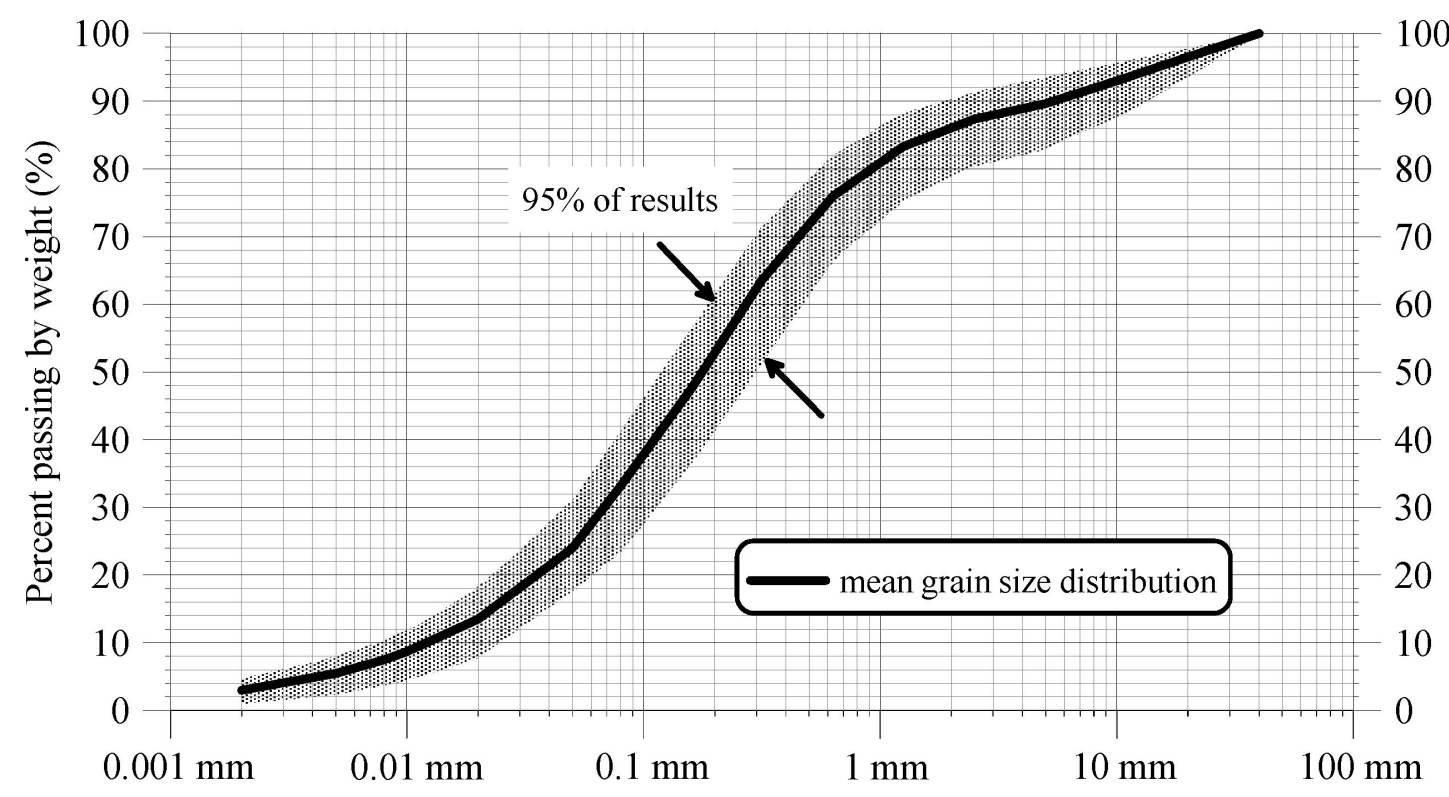

Figure 1 : Grain size distributions in till core. 
a dam. Moreover, the beneficial effects of having wide cores and filters in the field was not taken into account. For these reasons, and also as suggested by the authors [Kenney, 1985], the expression "potential for instability" is used in this study.

The application of the KL method requires the construction of a modified grain size distribution curve for each soil sample where the percentage $P$ of particles having a diameter between $d$ and $4 d$ (for $d \leq D_{20}$ ) [Kenney, 1986] should be higher than the percentage of particles smaller than $d$ to have internal stability :

$$
P(d \text { to } 4 d)>P(<d) \text { for } d \leq D_{20} \text {, }
$$

A simpler graphical procedure was suggested [Chapuis, 1992] in which for a particle size $D_{y}\left(y \leq D_{20}\right)$, the slope per cycle of the gradation curve, where $x=\log (d)$, must be higher than $1.66 y$ to have internal stability :

$$
\frac{y-y_{0}}{x-x_{0}}=1.66 y
$$

A development of equation [2] is suggested here to simplify further the application of the KL method. Equation [2] can be rewritten as :

$$
\frac{d y}{d x}=1.66 y,
$$

The integration of equation [3], between $y_{0}$ and $y$, leads to :

$$
\begin{gathered}
\ln \left(\frac{y}{y_{0}}\right)=1.66 \log \left(\frac{d}{d_{0}}\right), \\
\frac{\log \left(\frac{y}{y_{0}}\right)}{\log (e)}=1.66 \log \left(\frac{d}{d_{0}}\right), \\
\frac{\log (y)-\log \left(y_{0}\right)}{\log (d)-\log \left(d_{0}\right)}=1.66 \log (e)=0.7209,
\end{gathered}
$$

The left hand side of equation [6] represents the slope of the gradation curve $\left(y \leq D_{20}\right)$ on a log-log plot. For a given soil sample, if this slope is $<0.7209$, the soil has potential for instability according to the KL method.
The grain size distributions of till samples considered in this case study show a linear behaviour in a log-log plot between $0.08 \mathrm{~mm}$ and $0.002 \mathrm{~mm}$ (see figure 3).

This linearity shows the self-similarity of rock fragmentation processes for till formation in the dam area during the latest glaciation [Turcotte, 1986] and is indicative of the fractal dimension of the soil.

The assessment of soil samples is made by comparing the slope of their grain size distributions, points A and B on figure 3, to the reference line for the KL method, points $\mathrm{A}$ and $\mathrm{C}$ on figure 3 . For example, slope A-B on figure 3 being flatter than 0.7209 per cycle (slope A-C), the soil is judged potentially unstable according to the KL method. The results for each comparison are shown on figure 4 where the stable and potentially unstable samples are represented according to their spatial locations shown on figure 2 .

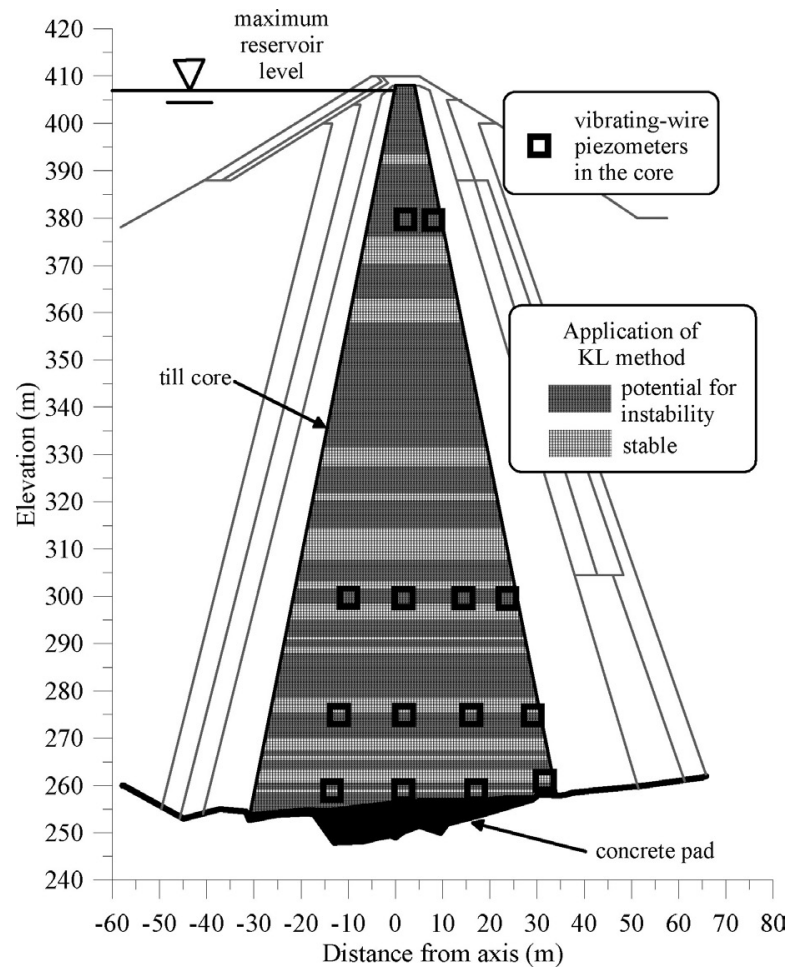

Figure 4 : Internally stable and potentially unstable zones in the dam core.

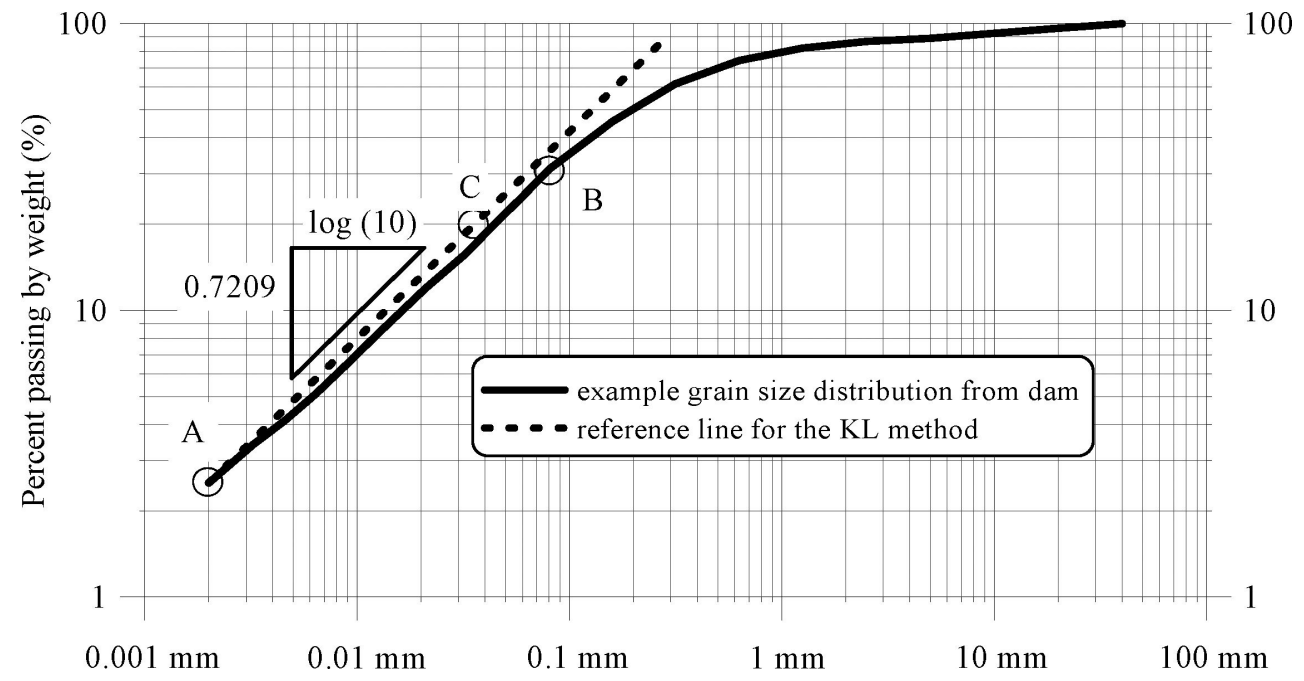

Figure 3 : Log-log representation of grain size distributions. 
According to figure 4, the largest portion of the dam core would show potential for instability.

\section{IV.2. WF method}

Soil samples were tested [Wan, 2008] to assess internal stability by various methods including the KL method which showed poor predictive ability for silt-sand-gravel soils. Improvements were proposed including an alternative method for well-graded soils which is used for this analysis. This method, referred to here as the WF method, compares the slope of the finer and coarser fractions of a soil using particle diameters corresponding to specific percentages passing. Stable, transition and unstable zones are defined using various diameter ratios (see figure 5).

The application of the WF method to the dam core grain size distributions (see figures 1 and 2) gave a range of values represented on figure 5 and located in the stable zone. According to the WF method, and contrary to the KL method, the entire dam core is deemed internally stable.

\section{IV.3. Lafleur method}

Various laboratory tests were realized [Lafleur, 1999] on well-graded till samples from northern Québec. Although the purpose of these tests was not specifically to establish an internal stability assessment method, the main conclusions of the study by [Lafleur, 1999] can be useful to analyze the till core presented here.

This study has shown internal stability of till (fraction passing $40 \mathrm{~mm}$ ) when the fines content $(<0.08 \mathrm{~mm})$ is more than $12 \%$. The fines content in the analyzed dam varies from $24 \%$ to $42 \%$ (see figure 1). According to the Lafleur method, the entire dam core is internally stable. This conclusion concurs with the findings from the application of the WF method.

\section{REPRESENTATIVENESS OF CONCLUSIONS DRAWN FROM THE APPLICATION OF THREE INTERNAL STABILITY ASSESSMENT METHODS}

\section{V.1. Practical implications of internal instability} in a dam core

Fines migration due to seepage forces in an internally stable core would be limited. There could be a redistribution of

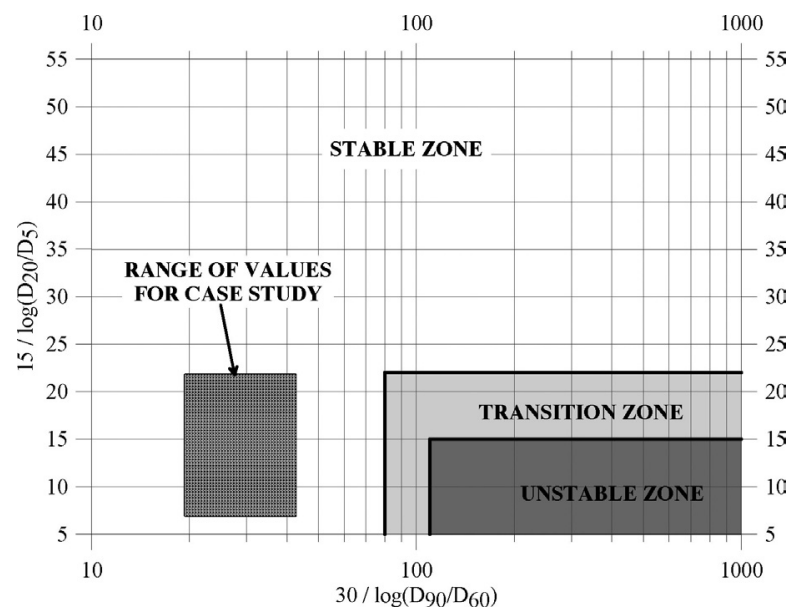

Figure 5 : WF method, range of values for the dam core. fines in the core, without loss of mass, which would cause local increases/decreases in hydraulic conductivity. Some of these soils can be referred to as self-filtering. The overall effect on the dam behaviour may not be significant enough to be detected by variations in seepage and pore pressure measurements.

Fines migration would be more significant in an internally unstable till core. The movement of fines can be stopped at the core-filter interface if the migrated particles are coarser than the constriction size of the downstream filter [Lafleur, 1999]. This concentration of fine particles would form in the vicinity of the filter interface a cake of material with a lower hydraulic conductivity than the bulk of core material. This behaviour would not cause a significant loss of mass in the core but, if widespread, could cause an increase in pore pressures and a decrease in seepage.

The fines migration in an internally unstable till core may not be stopped if the constriction size of the downstream filter is too large. This phenomenon would cause a loss of mass and permanent damage to the core. There would be a significant increase in seepage. Pore pressures may also be affected depending on the extent of zones with lost fines.

The application of three internal stability assessment methods for an existing dam led to contradictory results. The representativeness of conclusions drawn from such applications should not be judged only by considering laboratory testing conditions used in establishing the various methods. The assessment must also take into account results from field monitoring data.

\section{V.2. Measured pore pressures}

The location of vibrating-wire piezometers installed in the core at station 1235 is shown on figure 4. A piezometer was positioned near the downstream filter at each of the four installation elevations to monitor an eventual crowding of equipotential lines near the core-filter interface. The saturation of the core, 10 years after the end of first impoundment, is completed as well as the transient effects (ex. gas dissolution) during core saturation.

The dissipation of pore pressures measured by the piezometers is shown on figure 6 where the $\mathrm{x}$-axis represents

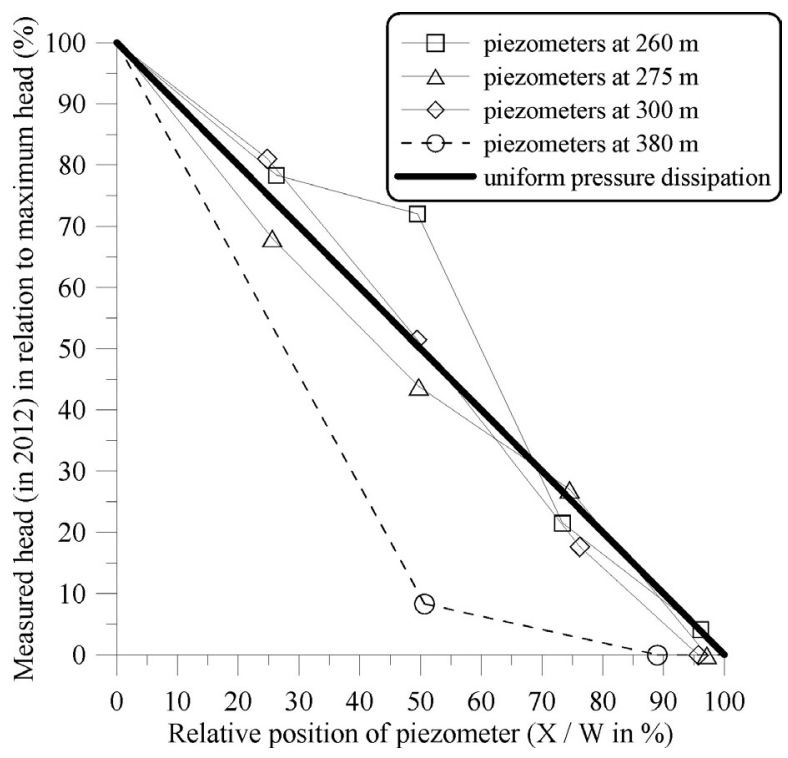

Figure 6 : Measured pore pressure dissipation. 
the relative position of each instrument $(X=$ distance from upstream edge of core and $W=$ width of core at a given installation elevation) and where the y-axis represents the ratio of measured pressure head over maximum pressure head (reservoir level - installation elevation).

Most of the measured pore pressures indicate a uniform pressure dissipation across the core. The instruments located near the core-filter interface $(X / W>90 \%)$ do not show increased pore pressures. Thus, a concentration of fines near the core-filter interface is not expected. The piezometers at elevation $380 \mathrm{~m}$ are the most affected by variations of the phreatic surface in the core due to variations in reservoir level.

Based on pore pressure measurements, widespread internal instability of the core and fines migration (without loss of mass) leading to concentration of fine particles in the vicinity of the core-filter interface are unlikely. However, piezometric results are only indicative of the core behaviour at specific areas. A global assessment can be realized by considering seepage measurements.

\section{V.3. Measured seepage}

A weir is installed at about $600 \mathrm{~m}$ from the downstream toe of the dam to collect seepage and allow its measurement. Figure 7 shows the measured seepage since first impoundment. The obvious effects of surface runoff (spring meltdown and rain) on the measurements were removed from the presented data.

A global trend can be identified in the measured seepage. After a steady increase during first impoundment, the seepage remained more or less constant since 2003. Based on the seepage measurements, widespread internal instability of the core and fines migration with loss of mass are unlikely.

\section{CONCLUSIONS}

An application of three internal stability assessment methods based on the geometry of grain size distributions (construction control data) was realized for the silt-sand-gravel core of a $171 \mathrm{~m}$-high rockfill dam. This led to contradictory results. The core had potential for internal instability for the method developed by testing sandy soils. The core was deemed internally stable by the two other methods developed by testing silt-sand-gravel soils. The representativeness of conclusions drawn from such applications should not be judged only by considering laboratory testing conditions used in establishing the various methods. The assessment must also take into account results from field monitoring data. For the presented case study, these results helped conclude that global internal stability in the core is likely.

The use of grain size distribution criteria is a first step to assess internal stability. A thorough assessment of the internal stability of an existing dam would require the analysis of the core and filter materials by considering the spatial variability of their geotechnical properties [see also Smith, 2011]. The interactions of the geometric, hydraulic and mechanical susceptibilities to internal instability would also have to be taken into account [see also Garner, 2010] as well as monitoring data.

The application of existing methods may not be sufficient to assess with confidence internal stability of soils to be used in new dam projects. Specific tests may be required particularly if the grain size distribution of soils under consideration is gap-graded or has a flat tail of fines.

\section{ACKNOWLEDGEMENTS}

The author wish to acknowledge Hydro Québec for permission to publish this paper.

\section{REFERENCES}

Chapuis R.P. (1992) - Similarity of internal stability criteria for granular soils. Canadian Geotechnical Journal. 29 : 711-713

GARNER S.J., FANNIN R.J. (2010) — Understanding internal erosion : a decade of research following a sinkhole event. International Journal on Hydropower and Dams. 17 : 93-98

KENNEY T.C., LAU D. (1985) - Internal stability of granular filters. Canadian Geotechnical Journal. 22 : 215-225

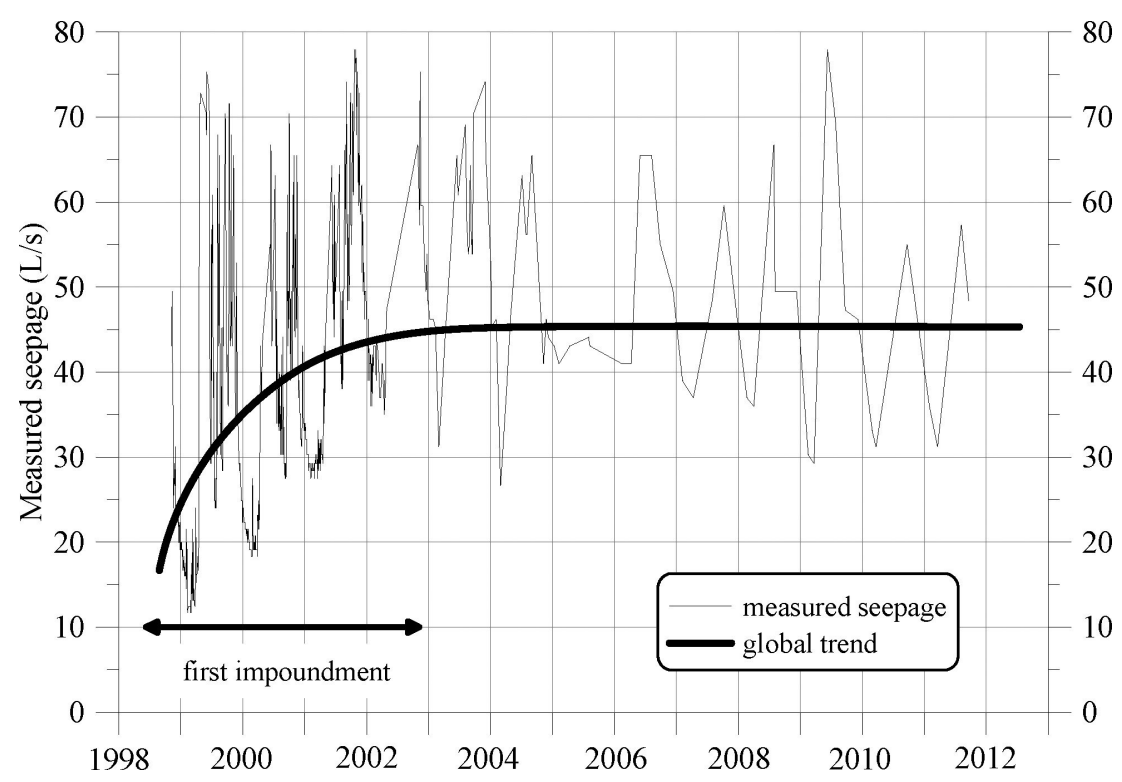

Figure 7 : Measured seepage. 
KENNEY T.C., LAU D. (1986) - Internal stability of granular filters : Reply. Canadian Geotechnical Journal. 23 : 420-423

Lafleur J., Montès P., Alicescu V. (1999) - Internal stability of particles in dam cores made of broadly-graded moraines. Canadian Geotechnical Conference. 52 : 551-558

Smith M., KonRad J.-M. (2011) — Assessing hydraulic conductivities of a compacted dam core using geostatistical analysis of construction control data. Canadian Geotechnical Journal. 48 : 1314-1327

Turcotte D.L. (1986) - Fractals and fragmentation. J. Geophys. Res. 91(B2) : 1921-1926

WAN C.F., Fell R. (2008) - Assessing the potential of internal instability and suffusion in embankment dams and their foundations. ASCE Journal of Geotechnical and Geoenvironmental Engineering. 134 : 401-407 